\title{
The identity of Hypolepis robusta, as a new synonym of Hypolepis alpina (Dennstaedtiaceae), based on morphology and DNA barcoding and the new distribution
}

\author{
Morigengaowa ${ }^{1,2}$, Jun-Jie Luo ${ }^{2,3}$, Ralf Knapp ${ }^{4}$, Hong-Jin Wei², Bao-Dong Liu', \\ Yue-Hong Yan², Hui Shang ${ }^{2}$
}

I Harbin Normal University, Key Laboratory of Plant Biology, College of Heilongjiang Province, Harbin 150025, China 2 Shanghai Chenshan Plant Science Research Centre, Chinese Academy of Sciences; Chenshan Botanical Garden, Shanghai 201602, China 3 College of Life and Environmental Sciences, Shanghai Normal University, Shanghai 200234, China 4 Correspondent of the Muséum National d'Histoire Naturelle (MNHN, Paris, France), Steigestrasse 78, 69412 Eberbach, Germany

Corresponding authors: Hui Shang (shanghui@csnbgsh.cn);Bao-DongLiu (99bd@163.com)

Academic editor: B. León | Received 7 January 2018 | Accepted 22 February 2018 | Published 15 March 2018

Citation: Morigengaowa, Luo J-J, Knapp R, Wei H-J, Liu B-D, Yan Y-H, Shang H (2018) The identity of Hypolepis robusta, as a new synonym of Hypolepis alpina (Dennstaedtiaceae), based on morphology and DNA barcoding and the new distribution. PhytoKeys 96: 35-45. https://doi.org/10.3897/phytokeys.96.23470

\begin{abstract}
Based on field observations and examinations of herbarium specimens (including type material), consulting the original literature and molecular phylogenetic analysis of the $r b c L$ and $\operatorname{trn} L-F$ sequences, it is concluded that Hypolepis robusta is conspecific with Hypolepis alpina and is here formally treated as a synonym of it. Additionally $H$. alpina is reported with new distribution records in Guangdong, Guangxi and the Hainan Island of China, respectively.
\end{abstract}

\section{Keywords}

Hypolepis alpina, molecular phylogenetic, synonym, taxonomy, Type material

\section{Introduction}

Hypolepis Bernh. (1805) is one of the largest genera in the family Dennstaedtiaceae, with approximately 80 species (PPG I 2016) widespread in tropical and southern temperate parts the world, mainly in tropical Asia and tropical America, but the

Copyright Morigengaowa et al. This is an open access article distributed under the terms of the Creative Commons Attribution License (CC BY 4.0), which permits unrestricted use, distribution, and reproduction in any medium, provided the original author and source are credited. 
exact number of species in China is still unclear (Brownsey 1987, Ching 1959, Xing et al. 2013). Amongst them, Hypolepis alpina (Blume) Hook. was initially described as Cheilanthes alpina Blume from Java in the first publication relating to the ferns of Malaya (Blume 1828). It was later transferred to Hypolepis by Hooker (1858) in the last comprehensive treatment of the genus (Brownsey 1987). Afterwards, one endemic species in the Taiwan province of China, Hypolepis alte-gracillima Hayata (1915), was reduced to a synonymy of $H$. alpina, according to the Flora of Taiwan (Shieh 1975). In addition to Taiwan, H. alpina is also distributed in Indonesia, Japan, Malaysia, Papua New Guinea and Philippines (Brownsey 1987, Fig. 1). Subsequently, the species (as H. alte-gracillima) was found in Gongshan County, in the Yunnan Province of China and recorded in Flora Yunnanica (Chu et al. 2006) as having a Yunnan-Taiwan discontinuous distribution. Another endemic species, H. robusta W. M. Chu was described for Yunnan (Chu et al. 2006). This name was treated as a synonymy of $H$. polypodioides (Blume) Hook. (Fraser-Jenkins 2008). Xing et al. (2013) cited a null name, (" $H$. robusta Hayata") as a synonym of $H$. polypodioides in Flora of China, but Hayata's name has not nomenclatural bearings nor taxonomic implications for Chu's name. However, even Chu's H. robusta is easily distinguishable from $H$. polypodioides in morphology as an obviously different species. Hypolepis robusta has densely multicellular brown glandular hairs and sori protected by well-developed reflexed adaxial indusium, whereas $H$. polypodioides has abundantly colourless non-glandular hairs and sori unprotected or occasionally protected by slightly reflexed green lamina segments. In June 2017, as part of the floristic inventory of Yunnan, $H$. robusta was collected at its type locality, Fugong County and $H$. alpina was collected at its recorded locality in Gongshan County. In addition, during the field work from 2013 to 2017, several specimens of $H$. alpina were collected from Taiwan as well as several others that were initially identified as H. robusta in Guangdong, Guangxi, Hainan Island and other locations of Yunnan. After conducting field observations, examinations of the herbarium specimens (including both types studied) and consulting the original literature (Hooker 1858, Chu 1992), it was suspected that $H$. robusta is conspecific with $H$. alpina. Therefore, the identity of $H$. robusta was determined by a more detailed examination of the morphology and molecular phylogenetic analysis.

\section{Materials and methods}

\section{Morphological studies}

For morphological comparisons, herbarium specimens or high-resolution images of specimens in CSH, K, KUN, L, P, PE, PYU, TAI, TAIF and US were critically checked. Field observations and collections were made in Guangdong, Guangxi, Hainan Island, Taiwan and Yunnan of China (Suppl. material 1: Table S1). 


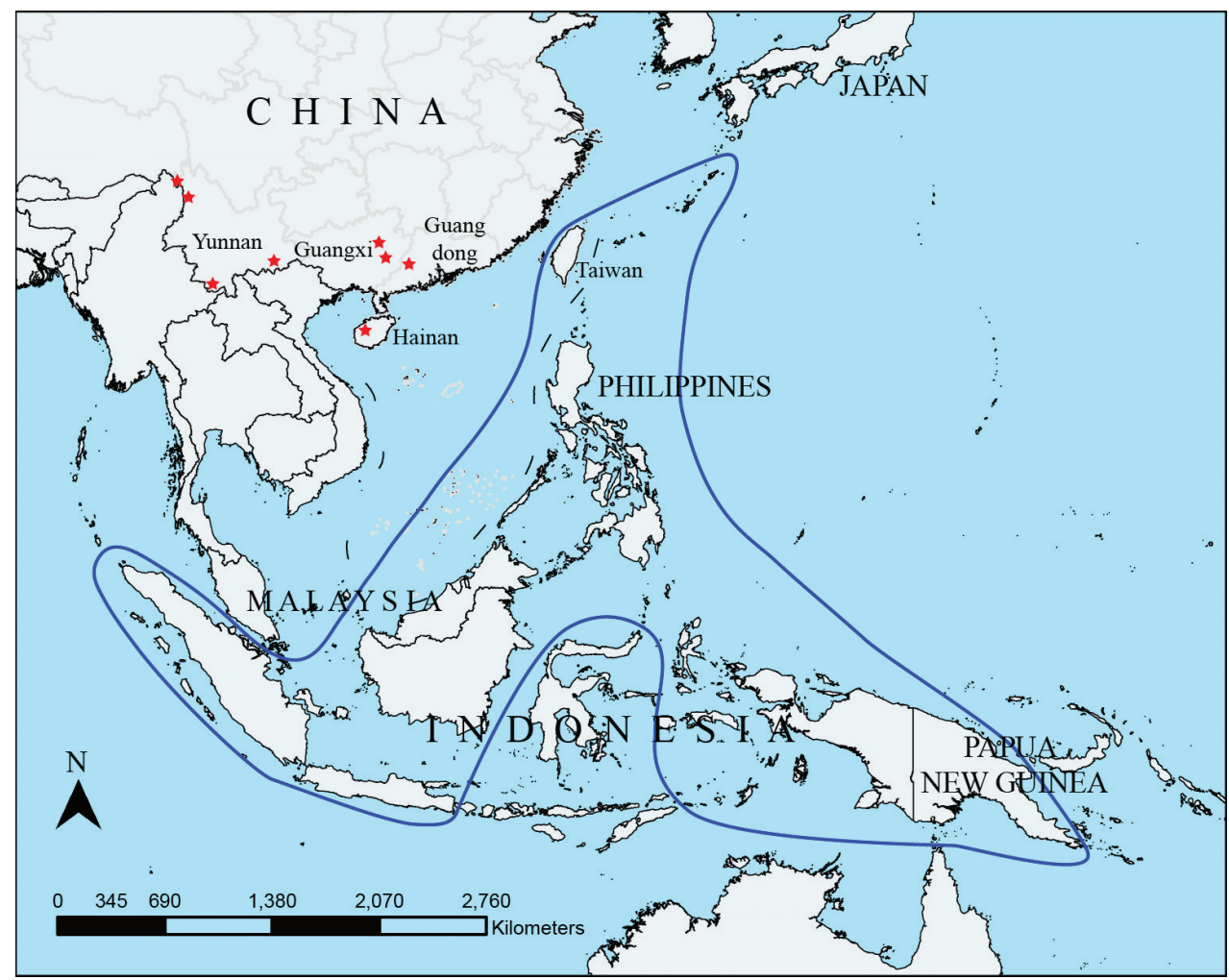

Figure I. The distributions of Hypolepis alpina noted by Brownsey (1987, blue line) and new record localities since then (red stars), using a map available from http://219.238.166.215/mcp/index.asp.

\section{Molecular phylogenetic studies}

Nineteen specimens were sampled, including the outgroup taxa Blotiella stipitata (Alston) Faden and Histiopteris incisa (Thunb.) J. Sm., Pteridium aquilinum subsp. wightianum (J. Agardh) W.C. Shieh. Total genomic DNA was extracted from silica gel-dried leaves by using a DNA secure Plant Kit (Tiangen Biotech, Beijing, China) according to the manufacturer's protocols. The PCR reactions were performed in a Veriti 96-Well Thermal Cycler. Two plastid markers were amplified, the $r b c L$ gene and the $\operatorname{trnL} L-\operatorname{trnF}$ intergenic spacer. Primers used for amplification and sequencing were: $r b c L$ primers $1379 \mathrm{R}$ and $1 \mathrm{~F}$ (Little and Barrington 2003) and trnL-F primers trn-F and trn-r1 (Taberlet et al. 1991, $\mathrm{Li}$ et al. 2011). The amplification profiles were: initial denaturation $\left(94^{\circ} \mathrm{C}, 3 \mathrm{~min}\right)$ followed by 29 cycles of amplification, hybridisation and extension $\left(94^{\circ} \mathrm{C}, 45 \mathrm{~s} ; 52^{\circ} \mathrm{C}, 30 \mathrm{~s}\right.$; $\left.72{ }^{\circ} \mathrm{C}, 1.5 \mathrm{~min}\right)$ and $10 \mathrm{~min}$ of final extension at $72^{\circ} \mathrm{C}$ for $r b c L$, initial denaturation $(95$ $\left.{ }^{\circ} \mathrm{C}, 3 \mathrm{~min}\right)$ followed by 35 cycles of amplification, hybridisation and extension $\left(95^{\circ} \mathrm{C}\right.$, $30 \mathrm{~s} ; 52^{\circ} \mathrm{C}, 30 \mathrm{~s} ; 72^{\circ} \mathrm{C}, 1 \mathrm{~min}$ ) and $10 \mathrm{~min}$ of final extension at $72^{\circ} \mathrm{C}$ for trnL-trnF. Sequencing was conducted using an ABI 3730xl DNA analyser (Applied Biosystems, Invitrogen, Foster City, CA, USA). 


\section{Phylogenetic analyses}

Sequences were assembled and edited with SeqMan (DNA STAR package; DNA StarInc., Madison, WI, USA), aligned by Bio Edit (Hall 1999) and adjusted manually where necessary. All sequences are available from GenBank (Table 1).

For phylogeny reconstructions, two methods were used, maximum likelihood (ML) and Bayesian Inference (BI). The ML analyses were conducted with RAxMLHPC BlackBox8.2.10 (Stamatakis 2014). For the Bayesian analyses, the best-fitting models $(\mathrm{HKY}+\mathrm{G})$ were selected using jModeltest 2 web server under the Bayesian Information Criterion (BIC) (Darriba et al. 2012). Four chains were used with random initial trees as BI settings. Trees were generated for 1,000,000 generations and sampling was conducted every 100 generations. Before stationarity was conducted, the first 2,500 trees were discarded as burn-in trees and the remaining trees were used to construct the majority-rule consensus trees. The remaining trees were used to construct a consensus tree. ML bootstrap values and BI posterior probabilities were labelled on the tree branches.

\section{DNA barcoding analyses}

For species delimitation between $H$. alpina and the other species of Hypolepis, the DNA barcoding gap method, based on the Kimura two parameter (K2P) distance, was used. Intra- and inter-taxa genetic distances were evaluated using MEGA 5.0 (Tamura et al. 2011).

\section{Results}

A total of 19 new sequences amongst the total of 19 specimens were generated in the cpDNA matrix of $r b c L$ and $t r n L-F$ containing 2,166 bp characters with 374 variable sites and 149 parsimony-informative sites. The optimal ML tree showed a negative $\log$-likelihood score $(-\ln \mathrm{L})$ of 5577.824547 and the Bayesian tree was consistent with the ML tree. The statistical support is shown along the branches (ML/BI). Individuals of $H$. alpina and $H$. robusta formed a highly supported monophyletic group with an MLBS of 100 as sister clades of $H$. tenuifolia. Moreover, all $r b c L$ and $t r n L-F$ sequences of the $H$. robusta, from type locality, were identical to those of $H$. alpina from Taiwan. The sequences of $H$. robusta from Guangdong, Guangxi and from Hainan Island were also clustered in the $H$. alpina clade, which had an MLBS of 100 (Fig. 2).

No differences were observed in the $r b c L$ and $\operatorname{trnL}-F$ barcoding sequences of both $H$. alpina and $H$. robusta, except that two specimens have two base differences respectively. The genetic distance between $H$. robusta and $H$. alpina ranges from zero to 0.002 . Their inter-taxon distances were significantly larger than their intra-taxon distances compared with the other species of Hypolepis and the ratio between the minimum inter-taxon distance and the maximum intra-taxon distance is 11 (Fig. 3). 
Table I. Plant materials, voucher information, and GenBank accession numbers of the samples used in the phylogenetic analyses. ${ }^{2}$

\begin{tabular}{|c|c|c|c|c|c|}
\hline \multirow{2}{*}{ Taxon } & \multirow{2}{*}{ Voucher } & \multirow{2}{*}{ Locality } & \multirow{2}{*}{$\begin{array}{l}\text { Geographic } \\
\text { coordinates }\end{array}$} & \multicolumn{2}{|c|}{ GenBank accession number } \\
\hline & & & & $r b c L$ & trnL-F \\
\hline $\begin{array}{l}\text { Hypolepis glandulifera Brownsey } \\
\text { \& Chinnock }\end{array}$ & BLD01 & Bali, Indonesia & NA & MG944782 & MG944788 \\
\hline Hypolepis robusta W.M. Chu & DRS005 & $\begin{array}{l}\text { Darong Mountain, Guangxi, } \\
\text { China }\end{array}$ & NA & MG944773 & MG944789 \\
\hline $\begin{array}{l}\text { Hypolepis punctata (Thunb.) } \\
\text { Mett. ex Kuhn }\end{array}$ & FLX6 & Hunan, China & NA & MG944784 & MG944790 \\
\hline $\begin{array}{l}\text { Hypolepis tenuifolia (G. Forst.) } \\
\text { Bernh. }\end{array}$ & HN31 & $\begin{array}{l}\text { Wuzhishan Mountain, Hainan, } \\
\text { China }\end{array}$ & $\begin{array}{l}18^{\circ} 55^{\prime} 1 " \mathrm{~N} \\
109^{\circ} 42^{\prime} 13 " \mathrm{E}\end{array}$ & MG944786 & MG944791 \\
\hline Hypolepis robusta W.M. Chu & HND6 & $\begin{array}{l}\text { Bawang Mountain, Hainan, } \\
\text { China }\end{array}$ & $\begin{array}{l}19^{\circ} 07^{\prime} 26^{\prime \prime} \mathrm{N} \\
109^{\circ} 04^{\prime} 46^{\prime \prime} \mathrm{E}\end{array}$ & MG944774 & MG944792 \\
\hline Hypolepis alpina (Blume) Hook. & Knapp4486 & Yilan County, Taiwan, China & $\begin{array}{l}24^{\circ} 49^{\prime} \mathrm{N} \\
121^{\circ} 41^{\prime} \mathrm{E}\end{array}$ & MG944769 & MG944794 \\
\hline Hypolepis robusta W.M. Chu & SG958 & $\begin{array}{l}\text { Shengtang Mountain, } \\
\text { Guangxi, China }\end{array}$ & NA & MG944777 & MG944801 \\
\hline Blotiella stipitata (Alston) Faden & SG1185 & Kenya & NA & MG944780 & MG944795 \\
\hline $\begin{array}{l}\text { Pteridium aquilinum subsp. } \\
\text { wightianum (J. Agardh) W.C. } \\
\text { Shieh }\end{array}$ & SG1760 & Yunnan, China & NA & MG944787 & MG944796 \\
\hline Hypolepis robusta W.M. Chu & SG1812 & $\begin{array}{l}\text { Ada Village, Fugong County, } \\
\text { Yunnan, China }\end{array}$ & $\begin{array}{c}26^{\circ} 49^{\prime} 5.6964 " \mathrm{~N} \\
98^{\circ} 53^{\prime} 36.715^{\prime \prime} \mathrm{E}\end{array}$ & MG944776 & MG944797 \\
\hline Hypolepis alpina (Blume) Hook. & SG1838 & $\begin{array}{c}\text { Dulongjiang Village, Gongshan } \\
\text { County, Yunnan, China }\end{array}$ & $\begin{array}{c}27^{\circ} 41^{\prime} 11.004^{\prime \prime N} \\
98^{\circ} 16^{\prime} 54.340 " \mathrm{E}\end{array}$ & MG944771 & MG944798 \\
\hline Hypolepis alpina (Blume) Hook. & SG1871 & $\begin{array}{c}\text { Dulongjiang Village, Gongshan } \\
\text { County, Yunnan, China }\end{array}$ & $\begin{array}{c}27^{\circ} 54^{\prime} 49.306^{\prime \prime N}, \\
98^{\circ} 20^{\prime} 37.03^{\prime \prime} \mathrm{E} \\
\end{array}$ & MG944772 & MG944799 \\
\hline Hypolepis resistens (Kunze) Hook. & SG2900 & $\begin{array}{l}\text { Bawangling Mountain, } \\
\text { Hainan, China }\end{array}$ & $\begin{array}{l}19^{\circ} 5^{\prime} 28 " \mathrm{~N} \\
109^{\circ} 10^{\prime} 59^{\prime \prime} \mathrm{E}\end{array}$ & MG944785 & MG944800 \\
\hline $\begin{array}{l}\text { Hypolepis polypodioides (Blume) } \\
\text { Hook. }\end{array}$ & SIWS28 & Sulawesi, Indonesia & NA & MG944783 & MG944802 \\
\hline Histiopteris incisa (Thunb.) J. Sm. & WYD016 & Guangdong, China & $\mathrm{NA}$ & MG944781 & MG944804 \\
\hline Hypolepis robusta W.M. Chu & WYD574 & $\begin{array}{c}\text { Dawu Mountain, Guangdong, } \\
\text { China }\end{array}$ & NA & MG944778 & MG944805 \\
\hline Hypolepis alpina (Blume) Hook. & YYH11628 & $\begin{array}{c}\text { Xitou Village, Nantou County, } \\
\text { Taiwan, China }\end{array}$ & NA & MG944770 & MG944803 \\
\hline Hypolepis robusta W.M. Chu & YYH12064 & $\begin{array}{l}\text { Mengsong Village, Jinghong } \\
\text { City, Yunnan, China }\end{array}$ & NA & MG944775 & MG944793 \\
\hline Hypolepis robusta W.M. Chu & ZXC8465 & $\begin{array}{l}\text { Gulinqing Village, Maguan } \\
\text { County, Yunnan, China }\end{array}$ & $\begin{array}{l}22^{\circ} 51^{\prime} 43.64 " \mathrm{~N} \\
104^{\circ} 0^{\prime} 15.59^{\prime \prime} \mathrm{E} \\
\end{array}$ & MG944779 & MG944806 \\
\hline
\end{tabular}

Note: NA = not available.

a: Specimens are deposited at the Shanghai Chenshan Botanical Garden Herbarium (CSH), except for voucher Knapp 4486, which is deposited at the Muséum National d'Histoire Naturelle (P).

\section{Discussion}

Hypolepis robusta was first reported by Chu (1992), being endemic to the Yunnan Province (Chu et al. 2006). After carefully comparing the type (including holotype and lectotype) of $H$. robusta and $H$. alpina, it was found that their morphological characteristics, e.g. the adventitious bud at stipe base, frond size, indusium and others (lamina, stipe, hair), are basically the same.

One of the main differences of $H$. robusta and $H$. alpina ( $H$. alte-gracillima), mentioned in the key in Flora Yunnanica, is that the former has a few adventitious buds 


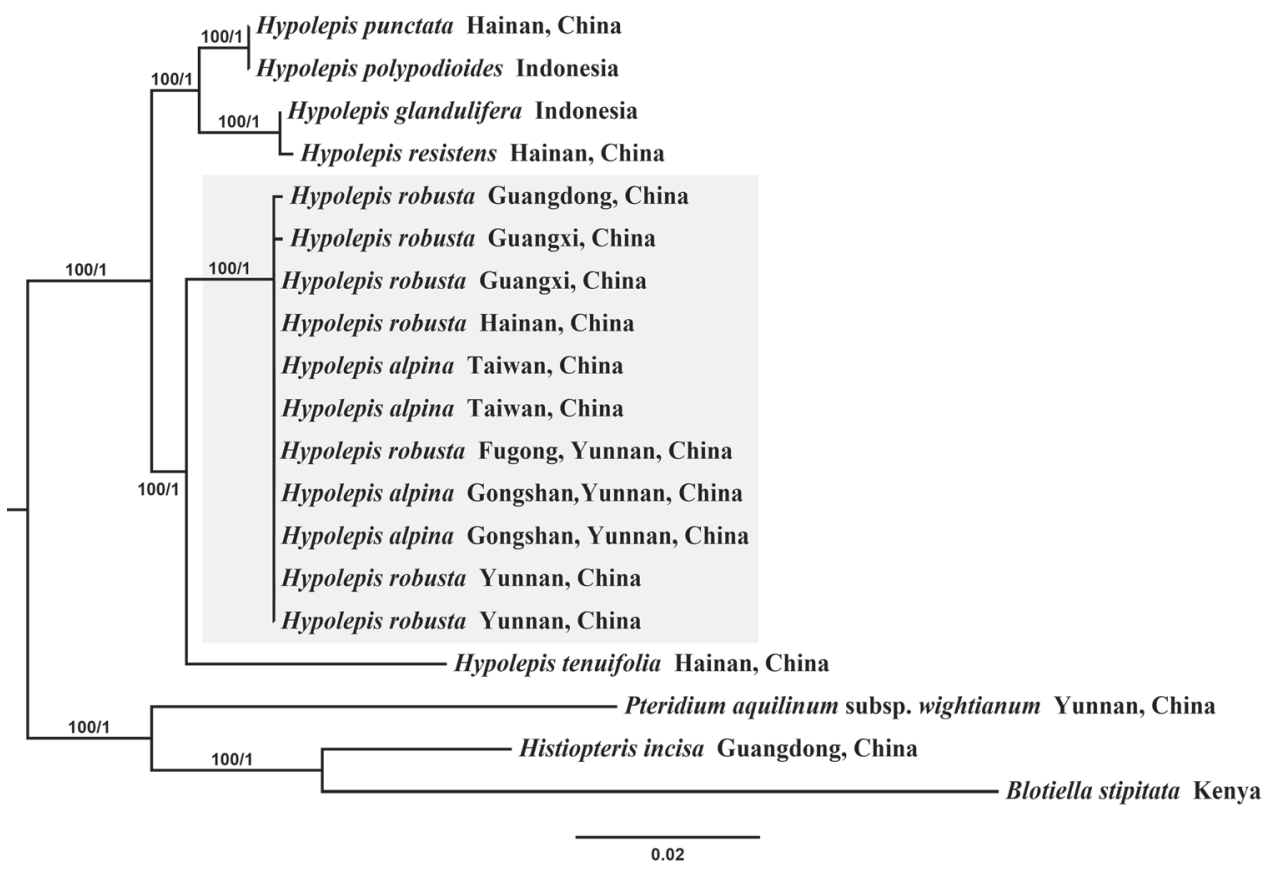

Figure 2. Phylogeny of 16 Hypolepis samples and Blotiella stipitata, Histiopteris incisa, and Pteridium aquilinum subsp. wightianum based on $r b c L$ and trnL-F. Bootstrap values and Bayesian posterior probabilities are shown along branches (ML/BI).

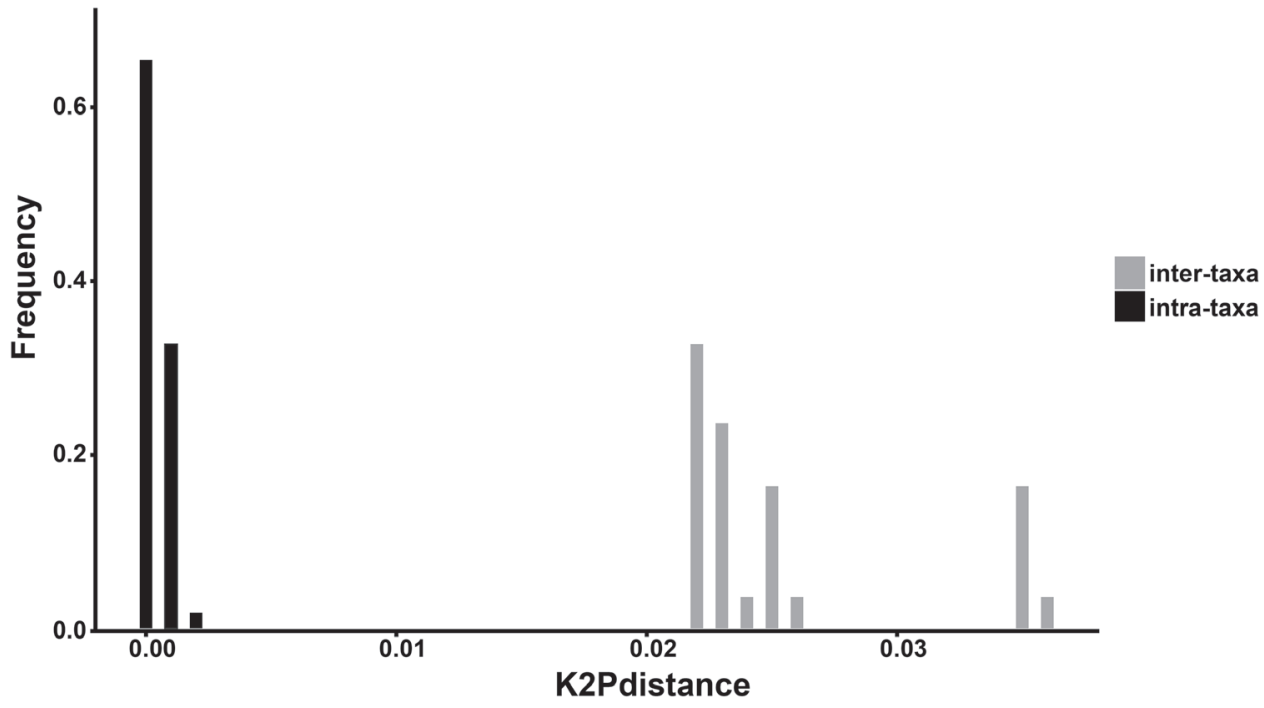

Figure 3. Distribution of intra-taxa (black) and inter-taxa (grey) Kimura two parameter (K2P) distances based on $r b c L$ and $\operatorname{trnL}-F$ sequences as barcode. Hypolepis alpina and Hypolepis robusta versus the other species of Hypolepis. 


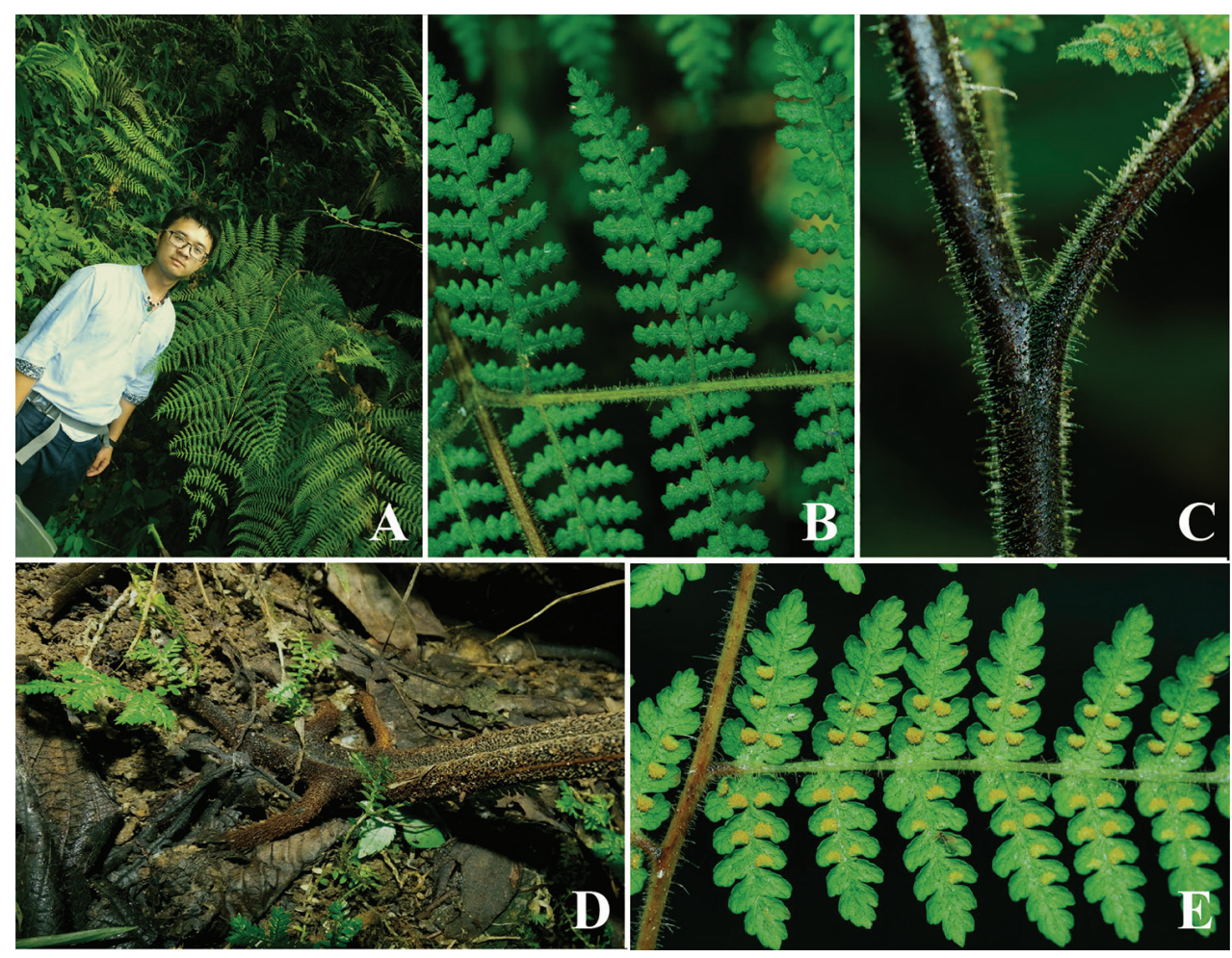

Figure 4. Hypolepis alpina. A Frond size (photographed by H. Shang in Fugong) B Lamina (photographed by R. Knapp in Nantou) C Hair (photographed by R. Knapp in Nantou) D The adventitious bud at stipe base (photographed by H. Shang in Fugong) E Indusium (photographed by R. Knapp in Nantou).

growing on both sides of the stipe base (Chu et al. 2006). However, when several specimens were examined in the herbarium and those from the authors' own collection, it was found that $H$. alpina also has this feature (Fig. 4D). Therefore, it is concluded that the character used in the description is not relevant for distinguishing between $H$. robusta and $H$. alpina. Moreover, other Asian species of Hypolepis also develop adventitious buds, such as $H$. pallida (Blume) Hook. and H. tenuifolia (G. Forster) Bernhardi.

Another character used to support $H$. robusta as a new species was its larger size than H. alpina. The latter was reported at higher altitudes in the Malaysian region, from about 1,500-3,500 $\mathrm{m}$ and also as low as 1,100 $\mathrm{m}$ on Mt Kinabalu in Borneo (Brownsey 1987). However, there is considerable variation between plants from the highest elevations in New Guinea, which have rather smaller fronds and a dense covering of chestnut-brown non-glandular hairs, to those at lower altitudes in the northern part of its range (notably Taiwan), which have large fronds and very few chestnut hairs (Brownsey 1987). According to the description in Flora Yunnanica, $H$. robusta has a little larger frond than $H$. alpina ( $H$. alte-gracillima). The field observation showed that $H$. robusta always occurs at altitudes about 1,000 m or even lower (Fig. 4A) and this is in accordance with the correlation between the altitudes and frond sizes mentioned in previous literature. 
The characters of the indusium have been widely used in fern taxonomy. According to the previous literature of $H$. alpina and $H$. robusta (Brownsey 1987, Chu et al. 2006), they could be distinguished morphologically as follows: H. robusta has white indusium with marginal laceration, but $H$. alpina has a reflexed broad green lamina flap. Based on careful observations of all available material, it was found that their indusia are both half membranaceous at the margins and still green at the base (Fig. $4 \mathrm{E})$. However, when the sori mature, the membranaceous margin becomes lacerated or exfoliated and the base can lose its chlorophyll, thus turning white. This difference may therefore be due to the fact that the descriptions have been made at different periods for the same species, a fact which had been previously ignored.

In addition to the morphological identification, a molecular phylogenetic analysis was also undertaken. The phylogenetic analysis of the $r b c L$ and $t r n L-F$ sequences strongly supported the monophyly of $H$. alpina and $H$. robusta as a phylogenetic species with a wide distribution and distantly related to $H$. polypodioides (Fig. 2). The DNA barcoding analysis based on the K2P model revealed a significant gap between the inter-taxon and intra-taxon genetic distances, the distance in the H. robusta and $H$. alpina clade range from zero to 0.002 , which is much lower than the inter-taxon distance and, in particular, the genetic distance between the $H$. alpina from Taiwan and the $H$. robusta from its type locality in Yunnan is zero (Fig. 3).

To sum up, not only does the morphological comparison identify $H$. robusta and $H$. alpina as conspecies, but also the phylogeny analysis identifies these as conspecies. Therefore, $H$. robusta is here reduced to a synonym of $H$. alpina. Consequently, $H$. alpina has three new distribution records in Guangdong, Guangxi and Hainan Island of China (Fig. 1). The new distribution records of $H$. alpina fill in gaps of the disjunct distribution defined in previous studies.

\section{Taxonomic treatment}

\section{Hypolepis alpina (Blume) Hook. (1852: 63)}

Hypolepis alpina (Blume) Hook. (1852: 63). Cheilanthes alpina Blume (1828: 138). Cheilanthes dissecta Hook. \& Arn. (1841: 75). Hypolepis dissecta (Hook. \& Arn.) Brack. (1854: 89-90). Hypolepis alte-gracillima Hayata (1915: 295-297).

Type: Indonesia. Java: Jawa Barat, Gede, Blume C. L. (Lectotype: L-0051753!, L-0051754!).

= Hypolepis robusta W. M. Chu (1992: 36), syn. nov.

Type. China. Yunnan: Fugong County, 1980, W. M. Chu (Holotype: PYU-01017821!, PYU-01017822!, PYU-01017823!, PYU-01017824!).

Fronds up to $1.7 \mathrm{~m}$ high. Rhizome long-creeping, 2-10 $\mathrm{mm}$ diameter, densely covered in red-brown hairs up to $3 \mathrm{~mm}$ long. Stipes reddish-brown, $12-70 \mathrm{~cm}$ long, $1.5-13 \mathrm{~mm}$ diameter, grooved adaxially, covered in red-brown non-glandular hairs 
up to $2 \mathrm{~mm}$ long and shorter glandular hairs, few adventitious buds at both sides of the stipe base; lamina ovate in outline, 3- or 4-pinnate, 20-80 $(-130) \mathrm{cm} \times$ $10-90 \mathrm{~cm}$, rachis red-brown or chestnut-brown at base, becoming chestnut-brown or yellow-brown at apex, densely covered in red-brown or chestnut-brown glandular hairs up to $0.5 \mathrm{~mm}$ long with occasional much longer non-glandular hairs; primary pinnae 15-30 pairs, opposite or sub-opposite, the largest at or near base, ovate to narrowly triangular, $10-52 \mathrm{~cm} \times 3-28 \mathrm{~cm}$; secondary pinnules narrowly ovate to ovate, $2-14 \mathrm{~cm} \times 0.8-5 \mathrm{~cm}$; ultimate pinnules to $10 \mathrm{~mm} \times 5 \mathrm{~mm}$. Sori circular or ovate, originating away from margins, without hairs between sporangia, protected by reflexed adaxial indusium, green at base and half membranaceous at margin, when the sori turn mature, the membranaceous margin becomes lacerated or exfoliated and the base part may turn white. Spores very pale under light microscope, perispores with interconnecting flattened projections, (32-) 34-37 (-40) $\mu \mathrm{m} \times(20-)$ $21-25(-28) \mu \mathrm{m}$.

Distribution. China (Guangdong, Guangxi, Hainan, Taiwan, Yunnan), Indonesia, Japan, Malaysia, Papua New Guinea, Philippines.

\section{Acknowledgements}

We thank Yu-Feng Gu, Ke-Rui Huang, Xi-Le Zhou and Zu-Xia He for their help in field investigations; special thanks go to Yea-Chen Liu, Kuan-Yu Shen, Da-Jun Lin and Yi-Hsuan Hsu for their help in field investigations and for taking photographs of specimens in Taiwan. We are grateful to the editor Dr. Blanca León and two anonymous reviewers for their very valuable suggestion in improve our manuscript. This study was supported by a grant from the National Natural Science Foundation of China (NSFC) to Hui Shang (\# 31700170) and Science and Technology Basic Work (2013FY112100).

\section{References}

Bernhardi JJ (1805) Dritter Versuch einer Anordnung der Farrnkräuter. Neues Journal für die Botanik 1(2): 1-50.

Blume CL (1828) Enumeratio plantarum Javae et insularum adjacentium: minus cognitarum vel novarum ex herbariis Reinwardtii, Kohlii, Hasseltii et Blumii, vol. 2. Lugduni Batavorum, Apud J.W. van Leeuwen, 138. https://doi.org/10.5962/bhl.title.44901

Brownsey PJ (1983) Polyploidy and aneuploidy in Hypolepis, and the evolution of the Dennstaedtiales. American fern journal 73(4): 97-108. https://doi.org/10.2307/1546960

Brownsey PJ (1987) A review of the fern genus Hypolepis (Dennstardtiaceae) in the Malesian and Pacific regions. Blumea-Biodiversity, Evolution and Biogeography of Plants 32(2): 227-276.

Ching RC (1959) Flora Reipublicae Popularis Sinica, vol. 2. Science Press, Beijing, 246. 
Chu WM (1992) Taxonomic notes on some pteridophytes from Yunnan (mainly Dulongjiang and neighboring regions). Acta Botanica Yunnanica 5: 36.

Chu WM, He ZR, Zhang GF, Lu SG (2006) Hypolepidaceae. In: Kunming Institute of Botany, Chinese Academy of Sciences (Eds) Flora Yunnanica, vol. 20. Science Press, Beijing, 236-238.

Darriba D, Taboada GL, Doallo R, Posada D (2012) jModelTest 2: more models, new heuristics and parallel computing. Nature Methods 9(8): 772-772. https://doi.org/10.1038/nmeth.2109

Fraser-Jenkins CR (2008) Taxonomic revision of three hundred Indian subcontinental pteridophytes: with a revised census list; a new picture of fern-taxonomy and nomenclature in the Indian subcontinent. Bishen Singh Mahendra Pal Singh, 85.

Hall TA (1999) Bio Edit: a user-friendly biological sequence alignment editor and analysis program for Windows 95/98/NT. Nucleic acids symposium series 41: 95-98.

Hayata B (1915) Icones plantarum formosanarum nec non et contributiones ad floram formosanam, vol. 5. Government of Formosa, Taihoku, 295-297.

Hooker WJ (1858) Species Filicum volume 2. Adiantum-Ceratoptcris. William Pamplin, London, 63. doi.org/10.5962/bhl.title.32186

Li FW, Kuo LY, Rothfels CJ, Ebihara A, Chiou WL, Windham MD, Pryer KM (2011) rbc $L$ and mat $K$ earn two thumbs up as the core DNA barcode for ferns. PLoS One 6(10): e26597. https://doi.org/10.1371/journal.pone.0026597

Little DP, Barrington DS (2003) Major evolutionary events in the origin and diversification of the fern genus Polystichum (Dryopteridaceae). American Journal of Botany 90: 508-514. https://doi.org/10.3732/ajb.90.3.508

PPG I [The Pteridophyte Phylogeny Group] (2016) A community-derived classification for extant lycophytes and ferns. Journal of Systematics and Evolution 54(6): 563-603. https:// doi.org/10.1111/jse.12229

Shang H, Wang Y, Zhu XF, Zhao GH, Wang FH, Lu JM, Yan YH (2016) Likely allopatric origins of Adiantum $\times$ meishanianum (Pteridaceae) through multiple hybridizations. Journal of Systematics and Evolution 54(5): 528-534. https://doi.org/10.1111/jse.12205

Shieh WC (1975) Dennstaedtiaceae. In: Li HL, Liu TS, Huang TC, Koyama T, CeVol CE (Eds) Flora of Taiwan, 1st edition, vol. 1. Epoch Publishing Co., Ltd, Taiwan, 243-247.

Stamatakis A (2014) RAxML version 8: a tool for phylogenetic analysis and post-analysis of large phylogenies. Bioinformatics 30(9): 1312-1313. https://doi.org/10.1093/bioinformatics/btu033

Taberlet P, Gielly L, Pautou G, Bouvet J (1991) Universal primers for amplification of three noncoding regions of chloroplast DNA. Plant molecular biology 17(5): 1105-1109. https:// doi.org/10.1007/BF00037152

Tamura K, Peterson D, Peterson N, Stecher G, Nei M, Kumar S (2011) MEGA5: Molecular evolutionary genetics analysis using maximum likelihood, evolutionary distance, and maximum parsimony methods. Molecular Biology and Evolution 28: 2731-2739. https:// doi.org/10.1093/molbev/msr121

Xing FW, Wang FG, Funston M, Gilbert MG (2013) Hypolepis. In: Wu CY, Raven PH, Hong DY (Eds) Flora of China, vol 2-3. Science Press Missouri Botanical Garden Press, Beijing, New York. 


\section{Supplementary material I}

\section{Table S1}

Authors: Morigengaowa, Jun-Jie Luo, Ralf Knapp, Hong-Jin Wei, Bao-Dong Liu, YueHong Yan, Hui Shang

Data type: (measurement/occurence/multimedia/etc.)

Explanation note: Herbarium specimens information of Hypolepis alpina and $\mathrm{Hy}-$ polepis robusta samples checked in this study.

Copyright notice: This dataset is made available under the Open Database License (http://opendatacommons.org/licenses/odbl/1.0/). The Open Database License $(\mathrm{ODbL})$ is a license agreement intended to allow users to freely share, modify, and use this Dataset while maintaining this same freedom for others, provided that the original source and author(s) are credited.

Link: https://doi.org/10.3897/phytokeys.96.23470.suppl1 